\title{
Management of micro and small businesses directed by women in Huejutla de Reyes, Hidalgo
}

\section{Gestión de las micro y pequeñas empresas dirigidas por mujeres en Huejutla de Reyes, Hidalgo}

HERRERO-VÁZQUEZ, Laura Leticiał, ESPINOSA-HERNÁNDEZ, Abraham, ROMEROESCUDERO, Carmina and RIVERA-MORALES, Claudia Eunice

Universidad Tecnológica de la Huasteca Hidalguense, Mexico.

ID $1^{\text {st }}$ Author: Laura Leticia, Herrero-Vázquez / ORC ID: 0000-0002-4891-0092, Researcher ID Thomson: Q-9835-2018, CVU CONACYT ID: 347168

ID $1^{\text {st }}$ Co-author: Abraham, Espinosa-Hernández / ORC ID: 0000-0001-5044-4396, Researcher ID Thomson: Q-98352020, CVU CONACYT ID: 344739

ID $2^{\text {nd }}$ Co-author: Carmina, Romero-Escudero / ORC ID: 0000-0001-5044-4396, Researcher ID Thomson: Q-9835-2020, CVU CONACYT ID: 34168

ID $3^{\text {rd }}$ Co-author: Claudia Eunice, Rivera-Morales / ORC ID: 0000-0001-5044-4396, Researcher ID Thomson: Q-98352020, CVU CONACYT ID: 347113

\begin{abstract}
The objective of this research is to analyze the level of functionality of the management of micro and small companies directed by women, through evaluating their processes with a systemic approach, which is composed as inputs of the variables inputs of the process, system processes and system results. The study included a representative sample of 327 companies. The information was collected through an instrument that includes 109 items on a five-level Likert-type scale applied by 180 students, previously trained for the application, as well as for data capture on a digital platform. The validation of the information generated in these two activities was validated by the present authors. Specifically, the variable with the best performance is production-operation (process) with a value of 4.2, where it is reflected that companies focus on the quality of their products, taking care of delivery times, as well as satisfaction of customers. On the other hand, the variable scope in sales is the one that shows the largest area of opportunity with a value of 3.0, this has to do with the expansion of sales outside its local sphere.
\end{abstract}

\begin{abstract}
Resumen
El objetivo de esta investigación es analizar el nivel de funcionalidad de la gestión de las micro y pequeñas empresas dirigidas por mujeres, mediante la valoración de sus procesos con enfoque sistémico, el cual se compone como entradas de las variables insumos del proceso, procesos del sistema y resultados del sistema. El estudio contempló una muestra representativa de 327 empresas. La recopilación de la información fue a través de un instrumento que contempla 109 ítems a una escala tipo Likert de cinco niveles aplicado por 180 estudiantes, previamente capacitados para la aplicación, así como para la captura de los datos en una plataforma digital. La validación de la información generada en estas dos actividades fue validada por los presentes autores. De forma específica se tiene que la variable con mejor desempeño es producción-operación (proceso) con un valor de 4.2, en donde se refleja que las empresas se enfocan a la calidad de sus productos, cuidando los tiempos de entrega, así como la satisfacción de los clientes. Por otra parte, la variable ámbito en ventas es la que muestra mayor área de oportunidad con un valor de 3.0, esta tiene que ver con la expansión de las ventas fuera de su esfera local.
\end{abstract}

Empresas, Mujeres, Gestión Reyes, Hidalgo. ECORFAN Journal-Republic of El Salvador. 2020. 6-11:25-30.

$\dagger$ Researcher contributing first author. 


\section{Introduction}

At present, the study of micro and small companies is a center of interest due to the relevance they have for the Mexican economy, having an important participation in the contribution to the national GDP, as well as the generation of jobs. above, it is important to have an analysis that allows recognizing its strengths but above all the weaknesses of the elements that comprise it; in such a way that strategies can be generated to improve their performance.

An important figure within these organizations is the participation of women, since the figures indicate that when the number of employed women employed the economy grows, also contributing to reduce the gap in gender equality, as referred to by the Organization of the United Nations (UN 2019), finding alternative benefits for the country such as the eradication of poverty, reducing exploitation and discrimination.

Therefore, there are currently various international agencies that promote actions that contribute to the empowerment of women by developing programs to promote the economic autonomy of women as well as show the contributions of women to the economy, as is the case of UN Women (UN 2019).

Specifically in Mexico, the UN Women shows the legislative advances with related issues in areas such as: wage equality, social security, gender equality, among others. For its part, the National Institute of Women (Inmujeres) and the Ministry of Economy joint efforts to increase the economic opportunities of women who live or have experienced violence, as well as mothers of disappeared women and / or girls or victims of femicide, who are in a vulnerable situation, to enable them to start a micro-business. (Inmujeres 2019).

Therefore, the development of this study is considered of interest, whose objective is to analyze the level of management functionality in the micro and small companies of Huejutla, directed by women to generate statistical information that allows us to visualize the status they present in the input, process and output variables, in such a way that once the areas of opportunity are identified, strategies are proposed that allow them to achieve organizational success and consequently increase the country's economy.

\section{Literature Review}

García, García and Madrid (2012) in their research called Characterization of the behavior of SMEs according to the gender of the manager: an empirical study, in the Region of Murcia, Spain, found that companies that are run by women are mainly found in the service sector (44.6\%), have a weak technological position $(10.7 \%)$, are smaller (the average sales of women's companies is 1'194,373 euros, while men have an average of 4,547,886 euros), and are above all of a family nature $(67.3 \%)$. In relation to performance, there is only a significant difference in the index of measurement of the rational characteristics, where it is stated that women present a lower performance than men. Likewise, it is concluded that there are many limitations for the entry and development of women within organizations; One of these is its social function and the obligations that it imposes on it and that affects the perceptions of its performance, which leads to working on a cultural change within organizations that is oriented to provide greater opportunities for development and growth. to the woman within it.

For his part, Saavedra 2020 in his study La Competitividad en MiPyMEs directed by Women in Mexico City, mentions that $49 \%$ of companies belong to the service sector, while $39 \%$ correspond to the commerce sector and only $12 \%$ are from the Industry sector, in terms of size, $92 \%$ correspond to micro companies, $7 \%$ are small companies and less than $1 \%$ correspond to medium-sized companies and $80 \%$ of companies are natural or natural persons, that is, they lack personality legal.

Regarding the characteristics, $60 \%$ of the businesswomen are over 40 years old, indicating that they have some work experience before starting a business, while $40 \%$ are under 40 years old, the same ones they undertake in order to balance work with family responsibilities. Regarding the studies carried out, the bachelor's level predominates $(36 \%)$ in the business area $(46 \%)$. On the other hand, $52 \%$ are married or have a partner, while the rest are single (35\%), and to a lesser extent they are divorced or widowed. 
This study concludes that the limitations of businesswomen are mainly due to insufficient business training and the fact that they continue to be responsible for the family and having the latter as a priority they are satisfied with the poor result and size of your company, constantly looking for the balance between both roles.

Marrugo (2016) in his study called "Women's access to decision-making positions in Colombian companies listed on the stock exchange" mentions that the industrial sector Colombia seems to be more receptive when it comes to placing women in the highest positions However, even in the rest of the economic sectors there is greater resistance to this change in mentality, not only from men but also from women themselves.In this sense, one of the main problems to combat is ingrained gender stereotypes and traditionally institutionalized in the structures and culture of organizations, whether public or private.

\section{Instrument}

As a data collection instrument for the present research, that of a macro research published by the Latin American Business and Administration Network proposed by Posada, Aguilar and Peña (2020) was taken up, which was previously validated (construct / reliability analysis), said The instrument measures the characteristics of the system of each micro and small company, from the perspective of a single person (the director or owner of the organization), who from their perspective valued the entry, process, exit and environment of their company. The instrument is structured by various sections, within which 105 items correspond to management strategies, divided in turn into: system inputs, market analysis, human resources, system processes, sales management, ISO 26000 matters and valuation. environment, a section is included at the beginning to collect sociodemographic aspects.

\section{Population and sampling}

The sample size was 361 companies, with which it was possible to obtain a confidence level of $95 \%$ and a maximum error of $5 \%$. However, the application included 514 companies, of which it was taken for the analysis of this document 328 which are headed by women. The collection of information was carried out through the training of 180 students for the application and for the capture of information on the platform.
Once this information was collected, it was validated by the authors of this research. The criteria for the selection of the sample were: to be of a micro and small size (from 2 to 50 workers, according to the classification by size in Mexico), to be located in Huejutla de Reyes and to belong to some of the activities contemplated in the classification of economic activities of the National Institute of Statistics, Geography and Informatics of Mexico.

\section{Design of the investigation}

The design of the present study is of a crosssectional type because the data collection was in a single time, it is also of a descriptive type, since it aims to investigate the level of the variables of the population.

\section{Results}

\section{Sociodemographic aspects}

Regarding the sociodemographic aspects, it is observed that the age of the female directors is concentrated between 33 and 39 years of age, as can be seen in graph 1, a fact that when compared with the figures provided by the literature for Mexico City has a contrary behavior.

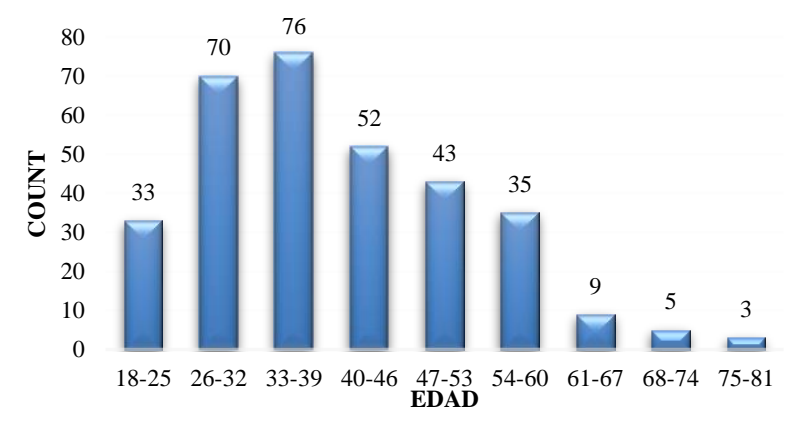

Graphic 1 Age of women

Source: Own elaboration

In terms of educational training, it was identified that there are three levels with high frequency, which are: completed secondary, completed undergraduate and completed high school, as can be seen in figure 2, these levels generally suggest that the majority (more than $50 \%$ of the population) has a medium and higher level of education; situation that could benefit when considering that there are current tools implemented in companies achieving better management. 


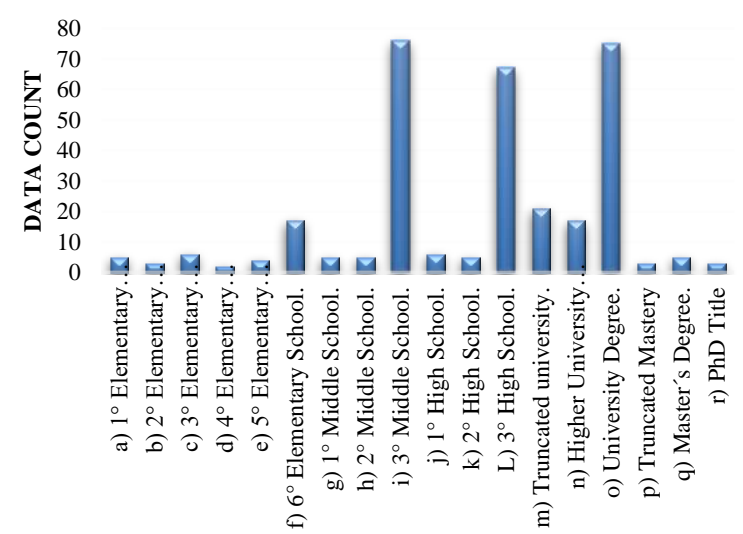

Graphic 2 Last year of studies

Source: Own elaboration

Regarding the founding of companies, it can be seen in Graphic 3, that most of the female executives are the ones who founded their business, demonstrating a significant level of entrepreneurship.

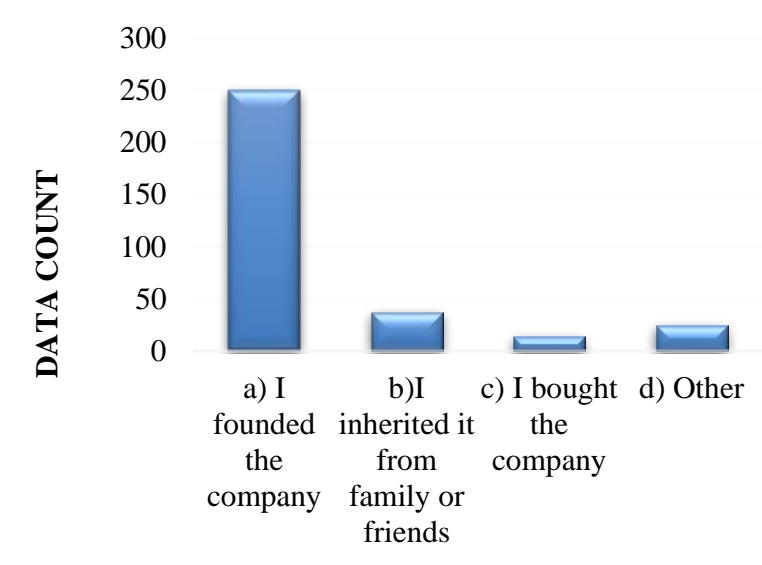

Graphic 3 How did you come to be the owner of this company?

Source: Own elaboration

On the other hand, when analyzing the time they invest in their businesses, a total of up to 12 hours was identified as the most frequent data, as shown in Graphic 4, the days greater than 15 hours a day are the ones with the lowest frequency.

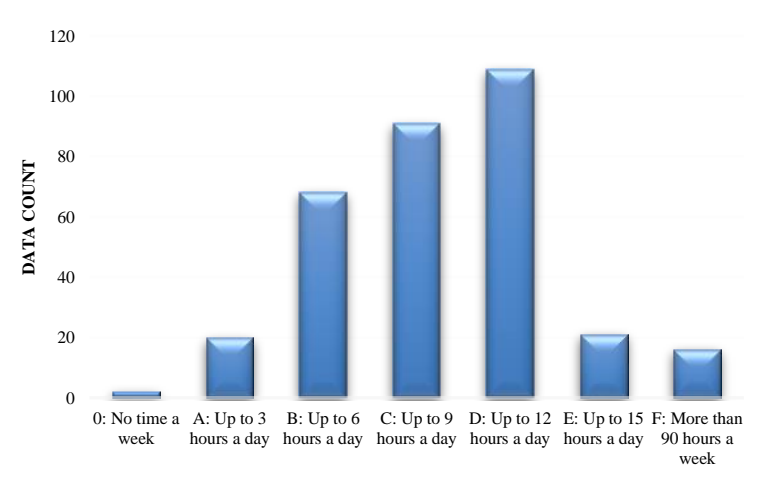

Graphic 4 How many hours a week do you dedicate to your company?

Source: Own elaboration
Now, once the time spent working in your company has been analyzed, the hours devoted to household chores were analyzed, here it is observed that the majority dedicate 3 hours; as shown in Graphic 5. The above is considered relevant for the analysis of the balance that women between their work and family responsibilities.

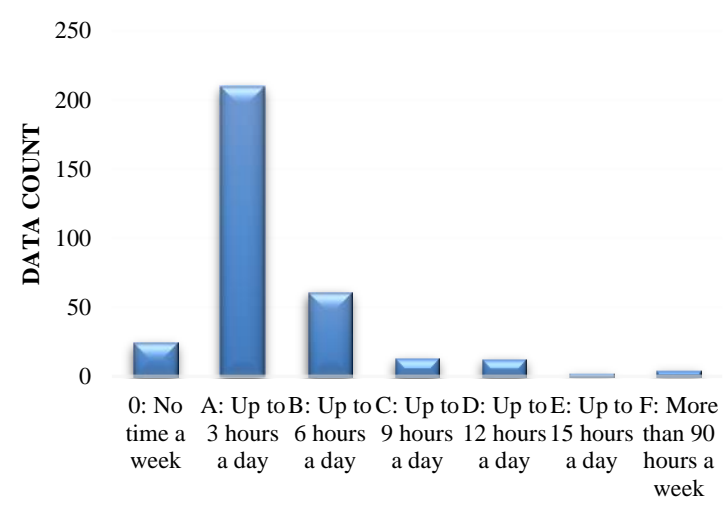

Graphic 5 How many hours a week do you dedicate to housework?

Source: Own elaboration

Finally, in terms of employability, it is observed in Graphic 6, that the companies run by women have mostly two employees, this shows their participation in the country's economy.

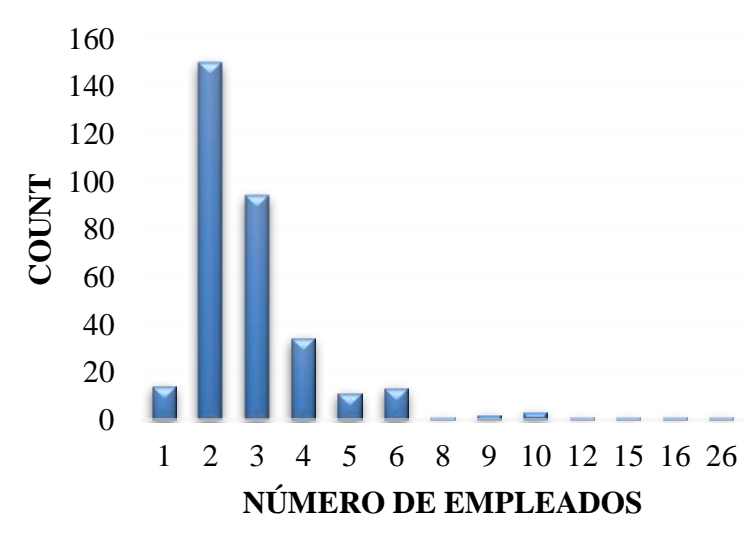

Graphic 6 Number of employees Source: Own elaboration

\section{Number of employees}

Regarding system inputs, the areas of human resources, market analysis and suppliers are considered, according to what is shown in Graphic 7, it is observed that the strongest is suppliers, indicating that the most important thing for the directives is that their suppliers give them the best price, quality products, permanent supply and that they give timely follow-up to their complaints. 


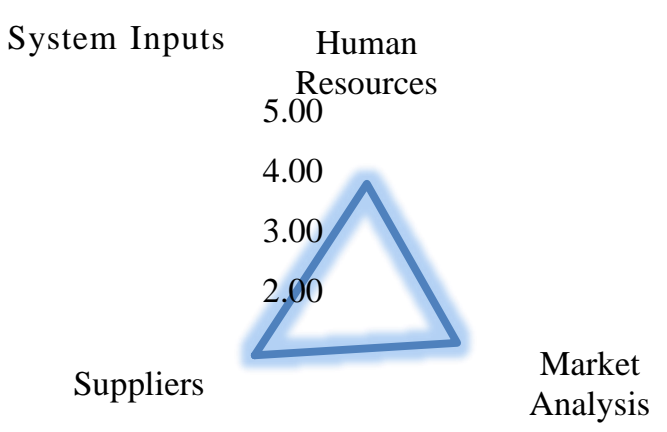

Graphic 7 System Inputs

Source: Own elaboration

Regarding process variables, it was identified that the area with the greatest strength is that of production-operation. which denotes an occupation of the directives to reduce their costs, as well as in the delivery in time and form of their products.

The areas of Management and Finance present a high valuation also which shows a high interest in activities related to the investment of profits for the growth of their businesses, seeking financing to make their company work, establishing clear objectives, planning expenses, as well as sales so as not to lose money.

On the other hand, the variable with the lowest value in process is innovation, which reflects the lack of development-oriented work to innovate the way in which they sell their products or services, the inclusion of employees to propose changes in products, services o processes and the infrequency of offering new products or services generated by the suggestion of customers. (Graphic 8).

\section{System Processes}

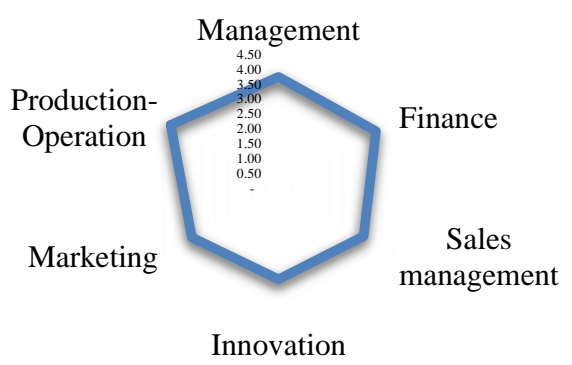

Graphic 8 System Processes

Source: Own elaboration
Finally, the analysis in the output or results of the system, the area with the highest value is that of competitive advantage (Graphic 9), where it is observed that women managers consider that clients choose their businesses for the good treatment they offer, because their product is the best in its category, because of the availability of your products and why they appreciate your brand.

In general, the areas of satisfaction with the company, assessment of the environment and ISO principles maintain an acceptable behavior.

The lowest value area corresponds to the sales area where it is observed that the directives do not consider customers from their neighborhood, city, government, other population and even abroad to extend their sales.

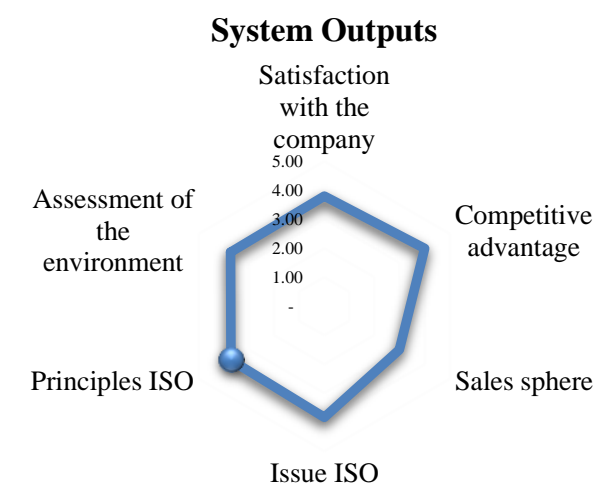

Graphic 9 System Results

Source: Own elaboration

\section{Conclusions}

The analysis of companies run by women shows us a large participation of female founders of micro and small companies, which mostly correspond to the retail trade, the age they have is from 33 to 39 years with an educational level of High school completed, although the baccalaureate and undergraduate levels are presented with a significant representation, the above can support the implementation of a greater number of strategies included in their organizations In terms of the balance between work and family, it was found that their effort is concentrated mostly in business, leaving little time dedicated to housework showing a family imbalance. It was found that the number of employees that they mostly have are 2 workers, leaving the possibility of analyzing whether the majority of them hire women, promoting labor equality. 
Regarding the analysis of the system in the input variables, the strength of the directives in activities that have to do with their suppliers is observed, taking care that they have continuous supply of products or services, that they offer the best prices and follow up on their complaints. The above can be translated (with its reservations) to the mentality focused on sales, since most of them are businesses dedicated to retail sales, having special concern for it in the relationship with their suppliers.

For the process variables, it is observed that the one of greatest interest is that of production-operation, repeating the efforts of the entrepreneurs to take care of costs, as well as the time and manner in the delivery of their products. It was found in the same way that the areas of management and finance are also high, it is considered that the latter may be due to the concern of entrepreneurs for the care of their money and for the regulation by the authority that is required today in day to every business and not necessarily as a measure that they visualize as a strategy to achieve better results, the foregoing subject to conducting a study for confirmation.

Finally, in the output variables, it is observed that competitive advantage is the one that presents the greatest value, which suggests that the businesswomen consider that customers like their products and that they appreciate their brand.

In general, the system of micro and small companies led by women shows a dynamism of traditional management, suggesting according to the results the implementation of a modern business management that allows them to compete in a globalized context.

\section{References}

García, M., García, D., y Madrid, A. (2012). Caracterización del comportamiento de las Pymes según el género del gerente: un estudio empírico. Cuadernos de Administración, 28, 3752.

https://www.redalyc.org/pdf/2250/2250250860 04.pdf

Saavedra, M. (2020). La competitividad en MiPyMEs dirigidas por mujeres en la Ciudad de México. Ciencias Administrativas, 15. https://doi.org/10.24215/23143738e 055
Marrugo, L. (2016). El acceso de la mujer a cargos de toma de decisiones en las empresas colombianas que cotizan en bolsa. Entramado, 12 ,

108-120.

https://www.redalyc.org/pdf/2654/2654470250 07.pdf

Posadas, R., Aguilar, O. y Peña, N. (2018). Método. En S. Delgado (Coord.), Potencial tecnológico de las micro y pequeñas empresas latinoamericanas a partir del análisis sistémico (tomo 1, pp. 23-33). Editorial Fontamara

Organización de las Naciones Unidas (2020) Trabajo y prioridades. https://www.unwomen.org/es/about-us/aboutun-women

Instituto Nacional de las mujeres. Estrategia Integral para Promover la Autonomía Económica de Mujeres en Situación de Violencia.

https://www.gob.mx/inmujeres/acciones-yprogramas/estrategia-integral-para-promoverla-autonomia-economica-de-mujeres-ensituacion-de-violencia-prueba-piloto. 